\title{
Non-native invasive species and novel ecosystems
}

\section{Daniel Simberloff}

Address: Department of Ecology and Evolutionary Biology, University of Tennessee, Knoxville, TN 37996, USA

Email: dsimberloff@utk.edu

Fl000Prime Reports 2015, 7:47 (doi:10.12703/P7-47)

All Fl000Prime Reports articles are distributed under the terms of the Creative Commons Attribution-Non Commercial License (http://creativecommons.org/licenses/by-nc/3.0/legalcode), which permits non-commercial use, distribution, and reproduction in any medium, provided the original work is properly cited.

The electronic version of this article is the complete one and can be found at: http://fl000.com/prime/reports/b/7/47

\begin{abstract}
Invasions by non-native species have caused many extinctions and greatly modified many ecosystems and are among the major anthropogenic global changes transforming the earth. Beginning in the mid-1980s, a dramatic burst of research in invasion biology has revealed a plethora of previously unrecognized impacts and laid bare the scope of the phenomenon. Similarly, research on various methods of managing invasions has expanded enormously, yielding incremental improvements in traditional methods and the advent of several new approaches, including the use of species-specific genetic and pheromonal methods. This research has advanced the field of restoration ecology, of which invasion management is a key component. Amidst this research progress, a group of critics has attempted to cast doubt on the extent of damaging impacts caused by non-native invasive species, the feasibility of counteracting them and restoring ecosystems, and the motives of scientists engaged in such endeavors. The criticisms are misguided but can potentially impede management of this pressing problem.
\end{abstract}

\section{Introduction}

Various non-native biological invaders have been noted for centuries, such as the phylloxera (a homopteran) that destroyed grapevines and devastated the wine industry in Europe in the 1860s [1] and the chestnut blight that entered North America in the early 20th century and virtually eliminated a dominant tree species [2]. By 1957, Charles Elton produced a series of $\mathrm{BBC}$ radio broadcasts about the general phenomenon of non-native invasions [3] and transformed the series into a book for a lay audience the next year [4]. Although particular invasions continued to attract great attention, Elton's book did not inspire a broad research thrust on invasions or a widespread public and policy response to their growing number. Rather, in the mid-1980s, an international project of the Scientific Committee on Problems of the Environment (SCOPE) engaged over 100 prominent scientists worldwide, produced several widely read edited volumes (for example, $[5,6]$ ), and triggered an explosion of research on invasions [3], which soon came to be recognized as one of the great ongoing global environmental changes, along with climate, nutrient cycle enhancement, and land-use changes [7].
This surge of research included many studies of how particular non-native invaders eat native species (for example, the brown tree snake in Guam [8] and the hemlock woolly adelgid in the eastern US [9]), compete with them (for example, the gray squirrel in Great Britain [10], crown vetch and tall fescue in the US Midwest [11], and the "killer alga" in the Mediterranean [12]), or infect them (for example, whirling disease of rainbow trout in the US [13]) and sometimes compete with them while vectoring diseases to them (for example, signal crayfish in Europe [14] and the gray squirrel in Great Britain [15]). However, two new lines of research have become increasingly prominent, both indicating that impacts of introduced species are more varied and widespread than had previously been thought.

First, in contributions to the SCOPE program, Peter Vitousek [16,17] described a different sort of impact. Rather than focusing on the population level (for example, as when the gray squirrel competes with the red squirrel in Great Britain and transmits squirrel pox) or the community level (affecting many species in the community, as when the brown tree snake eats all of 
the forest bird species in Guam), he depicted impacts at the ecosystem level: invasions that affected nutrient cycles and other ecosystem-level processes and features (such as fire cycles or hydrology). Research on such impacts in a variety of ecosystems has increased greatly, particularly in the new century $[18,19]$, showing how a single introduced species can change processes or the physical structure of an ecosystem, or both, sometimes subtly and slowly, but in such a way as to affect a large fraction of the resident species, as in the study by Fukami et al. [20] on impacts of introduced rats on seabirds and many aboveground and belowground organisms on islands.

The other major new direction of invasion biology is a greatly increased focus on genetics and evolution as increasingly sophisticated and accessible molecular genetic techniques become available. Molecular genetic research has increasingly revealed a great number of cases of the "stealth" impact of invaders, hybridization, and introgression with native species (for example, [21]). The phenomenon had previously been detected almost exclusively phenotypically [22], but many phenotypic responses are sufficiently subtle that they are hidden amidst the normal variation of many natural populations. It is now recognized that substantial introgression can occur even between native species that never hybridize when a newly introduced species constitutes a genetic bridge between them [23]. Introgression can also cause substantial evolution of native species, as in the European wildcat, which hybridizes with feral domestic housecats [24]. Hybridization between native and introduced species can even produce new, more invasive species; the best-known example is common cordgrass, Spartina anglica, an invader that arose in England from hybridization between native S. maritima and North American S. alterniflora [21]. In addition to showing the great extent of hybridization between introduced and native species, molecular genetic features such as microsatellites, mitochondrial DNA, and singlenucleotide polymorphisms have increasingly been used to trace sources and routes of invasions (for example, [25]). A major finding is that introduced populations often combine genes derived from multiple source populations, thus producing novel genetic combinations (for example, [25]). In fact, some introduced populations arising from multiple sources have more genetic variation than any single source population (for example, [25]). Also, environmental DNA ( $\mathrm{eDNA}$ ) is increasingly used to detect invaders [26] and played a key role in showing the great advance of Asian carp toward the Great Lakes [27].

The burst of research in the wake of the SCOPE project also revealed an increasing number of cases of "invasional meltdown" [28], in which two or more introduced species facilitate one another's establishment or enhance one another's impact on native species [29], as when the "honeydew" from introduced scale insects increases introduced ant populations [30] or when introduced birds disperse seeds of introduced plants [31]. In addition, an increasing number of "lag effects" have been detected, in which full-fledged widespread establishment and impact of an introduced species lags for years behind initial arrival. The reasons for such lags are various [32], and some remain mysterious, but the commonness of the phenomenon cannot be doubted.

\section{A reaction and response}

The many threads of 25 years of increasingly intensive research on biological invasions all lead to the conclusion that problems caused by the phenomenon are numerous, often tremendously important ecologically or economically worldwide, and growing apace with globalization $[33,34]$. Amidst this plethora of publications, a small but persistent group of critics has assailed the field of invasion biology and much of the invasion management effort on a variety of grounds [35], eliciting a spirited response [36]. Some critics go so far as to call for an end to invasion biology as a scientific discipline [37-39]. The objections fall primarily into five categories [40]: (1) The problems are overblown, and similar impacts arise from native species; most introduced species are not problematic. (2) In some instances, introduced species increase native biodiversity. (3) The antipathy toward introduced species is xenophobic. (4) In the face of globalization, we cannot substantially slow the spread of invasions; it is a hopeless battle. (5) For sentient animals, such as mammals, the methods used to combat invasive species are inhumane; in any event, individuals of the targeted species have a right to exist.

Criticism 5, which is part of a philosophical dispute that is not near resolution, revolves around the issue of the relative weight of rights of individuals and rights of collective entities such as species [41]. Consideration of criticism 2-which is based on the fact that, in some local biotas, the number of established introduced species exceeds the number of native species locally eliminated (whether because of introduced species or not)-should be tempered by the fact that many complete species extinctions have been wholly or partly caused by introduced species, especially but not exclusively on islands $[34,42]$. In addition, in many instances, species populations, though not eliminated, are reduced to a small fraction of their previous numbers. Biodiversity in terms of species numbers is not lost, but there is a major functional and demographic change. Criticism 3 is an assertion, generally leveled as part of a social 
construction of the science of invasion biology and management with scant or no regard for the impacts of invasions that are the stated purpose of the disputed activities [41,43].

The key criticisms from an ecological standpoint are 1 and 4: which introduced species really cause harm, and can we really do anything about it if they do? It is true that most introduced species are not known to cause significant harm. However, modern invasion biology is very new $[3,44]$, and the great majority of introduced species have not been studied in their introduced ranges, and so it is not possible to say that they have no significant impact. Perhaps the most comprehensive study of this matter [45] found, for Europe, that for only ca. $10 \%$ of some 11,000 introduced species has impact been documented, but that this is likely to underestimate the number actually causing impacts because of the dearth of research. One of the major recent research thrusts of invasion biology, as noted above, is unraveling various ecosystem impacts, some of which are initially subtle and take a long time to be manifested (for example, shifts in nutrient cycling). Vilà et al. [45] also found that, of introduced terrestrial vertebrates and freshwater plants and animals, about $30 \%$ are known to have harmful impacts.

In addition, the lag effect noted above [32] suggests that it would be foolhardy to wait for an impact to be recognized before acting. By then, the invader may well have spread beyond the point at which eradication or containment is possible. Furthermore, although some native species in certain circumstances (almost always associated with some other anthropogenic environmental change [46]) do cause impacts of the sort frequently associated with introduced invaders [47], the relative frequency of such impacts is far less than for non-native species $[46,48,49]$. Meanwhile, there is growing recognition of the great extent and variety of impacts of introduced species $[33,34]$. The lag effect, the subtlety of some impacts that have been occurring from the outset of the introduction, and the greater propensity for nonnative species to cause harm mean that the suggestion [35] to manage invasions only after impact is evident is ill advised.

Attempts to identify which species, if introduced, would be likely to become invasive have had some success (for example, [50]), inspiring the construction of several risk assessment tools, especially for plants [51]. The most prominent is the Australian Weed Risk Assessment (AWRA) [52], which has been refined and adapted for use in permitting introductions in many other regions. None of these tools is foolproof (for example, the AWRA fails to reject about $10 \%$ of known invasive plants in Australia), and the multiplicity of factors (including chance) that affect whether an introduced population survives, spreads, and becomes invasive will certainly limit their accuracy [51]. Nevertheless, they have been valuable in preventing some planned introductions that would likely have led to invasions, and the same tools can be used to identify recently introduced, restricted populations that should be prioritized for rapid attempts at eradication or containment.

The effort to prevent invasions or to reverse or mitigate their impacts is not hopeless [53]. Biosecurity can be very effective, as evidenced by great improvements in New Zealand as interdiction procedures became more stringent (for example, [34]). The impediments to improved biosecurity are primarily sociopolitical and economic, not technological. Similarly, the technology exists for greatly improved early detection and rapid response [33,53]; employing them is a matter of political will. Once a population is established, it is possible in some cases to eradicate it, and the technology to do so has improved greatly [53]. Increasingly ambitious eradication projects are being undertaken, and they are marked by striking successes; the current frontiers for vertebrate eradications are attempts to eradicate multiple species simultaneously, attempts to eradicate invasive species on larger islands and even continents, and attempts to eradicate invasive species on islands inhabited by humans (unpublished data). Terrestrial plants, insects, and aquatic organisms have been the most refractory targets for eradication. However, there have been striking eradication successes even for these taxa when populations have not yet spread widely beyond the initial introduction site (for example, [54,55]).

When eradication fails or is not attempted, many technologies can be employed to maintain populations of invaders at low densities [53]. The main, widely applied approaches are physical control (such as pulling weeds by hand), mechanical control (use of machinery), chemical control (use of herbicides and pesticides), and biological control (introduction of natural enemies of a target invader, from its native range). Each of these methods has succeeded in many instances and failed in others, and sometimes these methods have had undesirable non-target impacts. However, incremental improvements in techniques for all of these methods are leading to higher success rates and fewer non-target impacts $[53,56]$.

Many other technologies have been successfully applied to particular taxa. For instance, sterile males have been used in many maintenance management and even eradication programs for insects, especially flies $[57,58]$, 
and pheromones have been used to disrupt lepidopteran mating [59] and to trap sea lampreys $[60,61]$. Efficacy of the Judas-animal technique, widely used in mammal control and eradication programs, has recently been greatly improved by the use of hormone injections to prolong estrus [62]. Autocidal methods using genetic manipulation were proposed in the 1960 s and 1970s but not implemented then. Today, with the advent of various genetic manipulation techniques, including transgenes, several such projects have advanced to the proof-of-concept stage, particularly for dipterans and fishes [63], and a similar approach has been proposed for plants [64]. In sum, it is simply untrue that it is futile to fight invasions.

\section{A related controversy}

A simultaneous and related call for the end of traditional restoration ecology [65-69] as part of a "new world order" [65] accompanied the calls for an end to invasion biology [39]. This is perhaps unsurprising, as a very large component of restoration ecology consists of eliminating or managing non-native invasive species $[70,71]$, and the underlying argument of the advocates of abandoning traditional restoration ecology in favor of "novel ecosystems" has been that the overwhelming forces of invasions by non-native species and climate change have rendered obsolete the entire notion of returning an ecosystem to some historical state. Among prominent advocates of promoting novel ecosystems and abandoning traditional restoration ecology are several of the critics of invasion biology and management [39], and authors of articles for lay audiences, such as Emma Marris $[72,73]$ and Fred Pearce $[74,75]$, have vigorously promoted both agendas.

The contention that novel ecosystems are so inevitable as to constitute "the new normal" [72] is incorrect on several grounds [76]. For one thing, "novel ecosystem" is undefined, at least in operational terms. In no instance is it stated what specific criteria show that an ecosystem is now novel or what thresholds it has passed to achieve this status. All ecosystems are constantly changing, even without anthropogenic influences [77-81], leading Pickett et al. [79] to propose the metaphor of the "flux of nature" to replace "balance of nature". Contrary to claims by advocates of fostering and molding novel ecosystems, modern restoration ecology does not attempt to recreate the past; rather, the goal is to reestablish the historical trajectory of an ecosystem before anthropogenic influences derailed it [71]. This goal has been endorsed by the United Nations Convention on Biological Diversity, the European Commission, and major non-governmental organizations such as the International Union for the Conservation of Nature [76].
Another problem with the rush to embrace novel ecosystems as a goal is that the sense that much of the earth is rapidly changing to some sort of novel condition is based partly on maps, such as the human global footprint [82], drawn at far too coarse a scale [76]. The claim that we can do nothing to redress anthropogenic changes is also unwarranted [76]. The field of restoration ecology is very young and has learned much in a short time from past mistakes [39,70]. Meta-analyses show considerable progress in achieving restoration goals in a variety of ecosystem types, and impressive specific cases abound [76]. There is no evidence that any particular ecosystem cannot be restored in the sense of modern restoration ecology; the impediments are economic and political, not scientific and technological [76]. This does not imply that society should undertake to restore every ecosystem; each case should be considered by all stakeholders in terms of desirability, cost, and resource availability [76].

\section{Influence of controversies}

Policymakers and the general public whose interests they should represent can easily be misled by what they perceive to be the existence of a scientific controversy, and policymakers have used such "controversies" to forestall action on environmental problems [83]. The "debate" about anthropogenic climate change comes immediately to mind. The drumbeat of claims that the entire enterprise of modern ecological restoration is futile can perniciously influence policy at a time when many nations are undertaking ambitious restoration projects, and the United Nations, the three Rio Conventions, and many governments and large non-governmental organizations have all called for greatly expanded restoration efforts [76]. At the least, the contention that novel ecosystems are inevitable and perhaps desirable encourages any tendency to delay prevention and redress of various harmful environmental impacts rather than to undertake new approaches and to devote new resources to long-term solutions to environmental problems [76]. The same inimical influences on policy are exerted by critics of invasion biology and management. For instance, Larson and Palmer [84], in a policy-oriented journal, not only cite "emerging thinking" about novel ecosystems without mention of any of the weaknesses of the concept but cite Davis et al. [35] and Schlaepfer et al. [85] as calling into question the damage caused by invasive species without mentioning that these authors represent a small minority of scientists or citing specific rebuttals of those articles $[36,86]$. Critics of invasion biology and restoration ecology are not likely to keep these vibrant growing fields from progressing scientifically, but they will be able to slow the transformation of scientific knowledge into actions on the ground. 


\section{Abbreviations}

AWRA, Australian Weed Risk Assessment; SCOPE, Scientific Committee on Problems of the Environment.

\section{Disclosures}

The author declares that he has no disclosures.

\section{References}

I. Pouget R: Histoire de la Lutte contre le Phylloxéra de la Vigne en France (1868-1895). Paris: Institut National de la Recherche Agronomique; 1989.

2. Freinkl S: American Chestnut. The Life, Death, and Rebirth of a Perfect Tree. Berkeley: University of California Press; 2007.

3. Simberloff D: Charles Elton - Neither founder nor siren, but prophet. In Fifty Years of Invasion Ecology. Edited by Richardson DM. New York: Wiley; 2010:I I-24.

4. Elton CS: The Ecology of Invasion by Animals and Plants. London: Methuen; 1958

5. Mooney HA, Drake JA (Eds.): Ecology of Biological Invasions of North America and Hawaii. New York: Springer; 1986.

6. Drake JA, Mooney HA, diCastri F, Groves RH, Kruger FJ, Rejmánek M, Williamson M (Eds.): Biological Invasions. A Global Perspective. Chichester, UK: Wiley; 1989.

7. National Research Council: Global Change. Ecosystems Research. Washington DC: National Academy Press; 2000.

8. Rodda $\mathrm{GH}$, Savidge $\mathrm{JH}$ : Biology and impacts of Pacific island invasive species. 2. Boiga irregularis, the brown tree snake (Reptilia: Colubridae). Pacific Sci 2007, 6 I:307-24.

9. Ellison AM, Bank MS, Clinton BD, Colburn EA, Elliott K, Ford CR, Foster DR, Kloeppel BD, Knoepp JD, Lovett GM, Mohan J, Orwig DA, Rodenhouse NL, Sobczak WV, Stinson KA, Stone JK, Swan CM, Thompson J, Von Holle B, Webster JR: Loss of foundation species: consequences for the structure and dynamics of forested ecosystems. Front Ecol Environ 2005, 9:479-86.

10. Gurnell J, Wauters LA, Lurz PWW, Tosi G: Alien species and interspecific competition: effects of introduced eastern grey squirrels on red squirrel population dynamics. J Anim Ecol 2004, 73:26-35.

II. Walck JL, Baskin JM, Baskin CC: Effects of competition from introduced plants on establishment, survival, growth and reproduction of the rare plant Solidago shortii (Asteraceae). Biol Conserv 1999, 88:213-9.

12. Meinesz A: Killer algae, rev pbk ed. Chicago: University of Chicago Press; 2001.

13. Bartholomew JL, Reno PW: The history and dissemination of whirling disease. Amer Fisheries Soc Symp 2002, 29:3-24.

14. Gherardi F: Understanding the impact of invasive crayfish. In Biological Invaders in Inland Waters: Profiles, Distribution and Threats. Edited by Gherardi F. Dordrecht. The Netherlands: Springer; 2007:507-42.

15. Rushton SP, Lurz PWW, Gurnell J, Nettleton P, Bruemmer C, Shirley MDF, Sainsbury AW: Disease threats posed by alien species: the role of a poxvirus in the decline of the native red squirrel in Britain. Epidemiol Infect 2006, I34:52 I-33.

16. Vitousek PM: Biological invasions and ecosystem properties: can species make a difference? In Ecology of Biological Invasions of North America and Hawaii. Edited by Mooney HA, Drake JA. New York: Springer; 1986:163-76.

\section{FlOOOPrime \\ RECOMMENDED}

17. Ramakrishnan PS, Vitousek PM: Ecosystem-level processes and the consequences of biological invasions. In Biological Invasions. A Global Perspective. Edited by Drake JA, Mooney HA, diCastri F, Groves RH, Kruger FJ, Rejmánek M, Williamson M. Chichester, UK: Wiley; 1989:281-300.
18. Ehrenfeld JG: Ecosystem consequences of biological invasions. Annu Rev Ecol Evol Syst 2010, 41:59-80.

19. Simberloff $D$ : How common are invasion-induced ecosystem impacts? Biol Invasions 201 I, I3:I255-68.

20. Fukami T, Wardle DA, Bellingham PJ, Mulder CPH, Towns DR, Yeates GW, Bonner KI, Durrett MS, Grant-Hoffman MN, Williamson WM: Above- and below-ground impacts of introduced predators in seabird-dominated island ecosystems. Ecology Letters 2006, 9:1299-307.

\section{FIOOOPrime
RECOMMENDED}

2I. Strong DR, Ayres DR: Ecological and evolutionary misadventures of Spartina. Annu Rev Ecol Evol Syst 2013, 44:389-4I0.

22. Rhymer J, Simberloff D: Extinction by hybridization and introgression. Annu Rev Ecol Syst 1996, 27:83-109.

23. McDonald DB, Parchman TL, Bower MR, Hubert WA, Rahel FJ: An introduced and a native vertebrate hybridize to form a genetic bridge to a second native species. Proc Nat Acad Sci (USA) 2008, 105: 10837-42.

FlOOOPrime

24. Randi E: Detecting hybridization between wild species and their domesticated relatives. Molec Ecol 2008, I7:285-93.

FlOOOPrime

RECOMMENDED

25. Kolbe JJ, Glor RE, Schettino LR, Lara AC, Larson A, Losos JB: Genetic variation increases during biological invasion by a Cuban lizard. Nature 2004, 43 I:I77-8I.

\section{FlOOOPrime
RECOMMENDED}

26. Kelly RP, Port JA, Yamahara KM, Martone RG, Lowell N, Thomsen PF, Mach ME, Bennett M, Prahler E, Caldwell MR, Crowder LB: Environmental monitoring. Harnessing DNA to improve environmental management. Science 344:|455-6.

\section{FlOOOPrime}

\section{RECOMMENDED}

27. Jerde $C L$, Chadderton WL, Mahon AR, Renshaw MA, Corush J, Budny ML, Mysorekar S, Lodge DM: Detection of Asian carp DNA as part of a Great Lakes basin-wide surveillance program. Can J Fish Aquat Sci 2013, 70:522-6.

\section{FlOOOPrime} RECOMMENDED

28. Simberloff $D$, Von Holle B: Positive interactions of nonindigenous species: invasional meltdown? Biol. Invasions 1999, I:2 I-32.

29. Von Holle B: Invasional meltdown. In Encyclopedia of Biological Invasions. Edited by Simberloff D, Rejmánek M. Berkeley: University of California Press; 201 I:360-4

30. O'Dowd DJ, Green PT, Lake PS: Invasional 'meltdown' on an oceanic island. Ecol Lett 2003, 6:812-7.

\section{FlOOOPrime}

\section{RECOMMENDED}

31. Woodward SA, Vitousek PM, Matson K, Hughes F, Benvenuto K, Matson PA: Use of the exotic tree Myrica faya by native and exotic birds in Hawai'i Volcanoes National Park. Pacific Sci 1990, 44:88-93.

32. Crooks JA: Lag times and exotic species: the ecology and management of biological invasions in slow-motion. Écoscience 2005, I 2:3 16-29.

33. Pyšek $P$, Richardson DM: Invasive species, environmental change and management, and health. Annu Rev Envt Resources 2010, 35:25-55.

34. Simberloff D, Martin J-L, Genovesi P, Maris V, Wardle DA, Aronson J, Courchamp F, Galil B, García-Berthou E, Pascal M, Pyšek P, Sousa R, Tabacchi E, Vilà M: Impacts of biological invasions: what's what and the way forward. Trends Ecol Evol 2013, 28:58-66. 
35. Davis MA, Chew MK, Hobbs RJ, Lugo AE, Ewel J], Vermeji G], Brown JH, Rosenzweig ML, Gardener MR, Carroll SP, Thompson K, Pickett STA, Stromberg JC, Del Tredici P, Suding KN, Ehrenfeld JG, Grime JP, Mascaro J, Briggs JC: Don't judge species on their origins. Nature 201I, 474:153-4.

36. Simberloff $D$, and I 40 other authors: Non-natives: I4I scientists object. Nature 20II, 475:36.

37. Davis MA: Invasion Biology. Oxford: Oxford University Press; 2009.

38. Valéry L, Fritz H, Lefeuvre J-C: Another call for the end of invasion biology. Oikos 2013, 122:1 143-6.

39. Simberloff D, Vitule JRS: A call for an end to calls for the end of invasion biology. Oikos 20I4, I23:408-13.

40. Simberloff $D$ : Biological invasions: much progress plus several controversies. Contributions to Science 2013, 9:7-16.

4I. Simberloff D: Nature, natives, nativism, and management: worldviews underlying controversies in invasion biology. Environ Ethics 2012, 34:5-25.

42. Lee WG: Islands. In Encyclopedia of Biological Invasions. Edited by Simberloff D, Rejmánek M. Berkeley: University of California Press; 2011:391-5.

43. Simberloff D: Confronting introduced species: a form of xenophobia? Biol Invasions 2013, 5:179-92.

44. Pyšek $P$, Hulme $P$ : Invasion biology is a discipline that's too young to die. Nature 2009, 460:324.

45. Vilà $M$, Basnou $C$, Pyšek $P$, Josefsson $M$, Genovesi $P$, Gollasch $S$, Nentwig W, Olenin S, Roques A, Roy D, Hulme PE: DAISIE partners: How well do we understand the impacts of alien species on ecosystem services? A pan-European, cross-taxa assessment. Frontiers in Ecol Envt 2010, 8:135-44.

\section{FlOOOPrime}

46. Simberloff D, Souza L, Nuñez MA, Barrios-Garcia MN, Bunn W: The natives are restless, but not often and mostly when disturbed. Ecology 2012, 93:598-607.

47. Simberloff D: Native invaders. In Encyclopedia of Biological Invasions. Edited by Simberloff D, Rejmánek M. Berkeley: University of California Press; 201 I:472-75.

48. Paolucci EM, Maclsaac HJ, Ricciardi A: Origin matters: alien consumers inflict greater damage on prey populations than do native consumers. Divers Distrib 2013, 19:988-95.

\section{FlOOOPrime \\ RECOMMENDED}

49. Hassan A, Ricciardi A: Are non-native species more likely to become pests? Influence of biogeographic origin on the impacts of freshwater organisms. Frontiers in Ecol Envt 2014, 12:218-23.

\section{FlOOOPrime}

\section{RECOMMENDED}

50. Rejmánek M, Richardson DM: What attributes make some plant species more invasive? Ecology 1996, 77:1655-61.

51. Londsdale M: Risk assessment and prioritization. In Encyclopedia of Biological Invasions. Edited by Simberloff D, Rejmánek M. Berkeley: University of California Press; 20I I:604-9.

52. Pheloung PC, Williams PA, Halloy SR: A weed risk assessment model for use as a biosecurity tool evaluating plant introductions. J Environmental Mgt 1999, 57:239-5I.

53. Simberloff D: Biological invasions: What's worth fighting and what can be won? Ecol Engin 2014, 65:1 12-2I.

54. Anderson LWJ: California's reaction to Caulerpa taxifolia: a model for invasive species rapid response. Biol Invasions 2005, 7:1003-16.

\section{FlOOOPrime}

\section{RECOMMENDED}

55. Bax N, Hewitt C, Campbell M, Thresher R: Man-made marinas as sheltered islands for alien marine organisms: establishment and world-first eradication of a marine pest. In Turning the Tide:
Eradication of Invasive Species. Edited by Clout M, Veitch D. Auckland, New Zealand: World Conservation Union (IUCN) Species Survival Commission; 2001:8.

56. Clout MN, Williams PA (Eds.): Invasive Species Management. A Handbook of Principles and Techniques. Oxford: Oxford University Press; 2009.

57. Dyck VA, Hendrichs J, Robinson AS (Eds.): Sterile Insect Technique. Principles and Practice in Area-Wide Integrated Pest Management. Dordrecht, The Netherlands: Springer; 2005.

58. Vreysen MJB, Robinson AS, Hendrichs J (Eds.): Area-Wide Control of Insect Pests. Dordrecht, The Netherlands: Springer; 2007.

59. Witzgall P, Stelinski L, Gut L, Thomson D: Codling moth management and chemical ecology. Annu Rev Entomol 2008, 53:503-22.

60. Sorensen PW, Vrieze LA: The chemical ecology and potential application of the sea lamprey migratory pheromone. J Great Lakes Res 2003, 29(Suppl I):66-84.

\section{FlOOOPrime}

RECOMMENDED

6I. Sorensen PW, Fine JM, Dvornikovs V, Jeffrey CS, Shao F, Wang J, Vrieze LA, Anderson KR, Hoye TR: Mixture of new sulfated steroids functions as a migratory pheromone in the sea lamprey. Nat Chem Biol 2005, I:324-8.

\section{FIOOOPrime RECOMMENDED}

62. Campbell KJ, Baxter GS, Murray PJ, Coblentz BE, Donlan CJ, Carrion GV: Increasing the efficacy of Judas goats by sterilisation and pregnancy termination. Wildl Res 2005, 32:737-43.

\section{FlOOOPrime} RECOMMENDED

63. Thresher RE, Kayes K, Bax NJ, Teem J, Benfey TJ, Gould F: Genetic control of invasive fish: technological options and its role in integrated pest management. Biol Invasions 2014, 16:1201-16.

64. Hodgins KA, Rieseberg L, Otto SP: Genetic control of invasive plants species using selfish genetic elements. Evol Applic 2009, 2:555-69.

\section{FlOOOPrime}

\section{RECOMMENDED}

65. Hobbs RJ, Arico S, Aronson J, Baron JS, Bridgewater P, Cramer VA, Epstein PR, Ewel J], Klink CA, Lugo AE, Norton D, Ojima $D$, Richardson DM, Sanderson EW, Valladares F, Vilà M, Zamora R, Zobel M: Novel ecosystems : theoretical and management aspects of the new ecological world order. Global Ecol Biogeogr 2006, I5:I-7.

66. Hobbs RJ, Higgs E, Harris JA: Novel ecosystems: implications for conservation and restoration. Trends Ecol Evol 2009, 24: 599-605.

67. Hobbs RJ, Higgs ES, Hall CM (Eds.): Novel Ecosystems: Intervening in the New Ecological World Order. Oxford: Wiley-Blackwell; 2013.

68. Seastedt TR, Hobbs RJ, Suding KN: Management of novel ecosystems: are novel approaches required? Front Ecol Environ 2008, 6:547-53.

69. Hobbs RJ: Grieving for the past and hoping for the future: balancing polarizing perspectives in conservation and restoration. Restor Ecol 2013, 21 :145-8.

70. Jordan WR III, Lubick GM: Making Nature Whole. A History of Ecological Restoration. Washington DC: Island Press; 2011.

7I. Clewell A, Aronson J: Ecological Restoration (2nd ed.). Washington DC: Island Press; 2013.

72. Marris E: The new normal. Conserv Mag 2010, 11:13-7.

73. Marris E: Rambunctious Garden: Saving Nature in a Post-Wild World. New York: Bloomsbury USA; 2011.

74. Pearce $F$ : True nature: revising ideas on what is pristine and wild. Environment 360; 2013. [http://e360.yale.edu/feature/ true_nature_revising_ideas_on_what_is_pristine_and_wild/2649/] 
75. Pearce $\mathrm{F}$ : On a remote island, lessons in how ecosystems function. Environment 360; 2013. [http://e360.yale.edu/feature/ on_a_remote_island_lessons_in_how_ecosystems_function/2683/]

76. Murcia C, Aronson J, Kattan GH, Moreno-Mateos D, Dixon K, Simberloff D: A critique of the "novel ecosystem" concept. Trends Ecol Evol 2014, 29:548-53.

77. Wiens J: The Ecology of Bird Communities. Vol 2. Processes and Variations. Cambridge: Cambridge University Press; 1989.

78. Hastings A, Hom CL, Ellner S, Turchin P, Godfray HCJ: Chaos in biology: is Mother Nature a strange attractor? Annu Rev Ecol Syst 1993, 24: I-33.

79. Pickett STA, Kolasa J, Jones CG: Ecological Understanding: The Nature of Theory and the Theory of Nature. New York: Academic Press; 1994.

80. Pickett STA, Ostfeld RS: The shifting paradigm in ecology. In A New Century for Resource Management. Edited by Knight RL, Bates SF. Washington, DC: Island Press; 1995:26I-79.
8I. Wu J, Loucks OL: From balance of nature to hierarchical patch dynamics: a paradigm shift in ecology. Quart Rev Biol 1995, 70:439-66.

82. Sanderson EW, Jaiteh M, Levy MA, Redford KH, Wannebo AV, Woolmer G: The human footprint and the last of the wild. BioScience 2002, 52:891-904.

83. Oreskes N, Conway EM: Merchants of Doubt. New York: Bloomsbury Press; 2010.

84. Larson BMH, Palmer C: Assisted colonization is no panacea, but let's not discount it either. Ethics, Policy and Environment 2013, 16:16-8.

85. Schlaepfer MA, Sax DF, Olden JD: The potential conservation value of non-native species. Conserv Biol 20I I, 25:428-37.

86. Vitule JRS, Freire CA, Vazquez DP, Nuñez MA, Simberloff D: Revisiting the potential conservation value of non-native species. Conserv Biol 20I2, 26:II53-5. 